\title{
Composition and evolution of volcanic aerosol from eruptions of Kasatochi, Sarychev and Eyjafjallajökull in 2008-2010 based on CARIBIC observations
}

\author{
S. M. Andersson ${ }^{1}$, B. G. Martinsson ${ }^{1}$, J. Friberg ${ }^{1}$, C. A. M. Brenninkmeijer ${ }^{2}$, A. Rauthe-Schöch ${ }^{2}$, M. Hermann ${ }^{3}$, \\ P. F. J. van Velthoven ${ }^{4}$, and A. Zahn ${ }^{5}$ \\ ${ }^{1}$ Division of Nuclear Physics, Lund University, Lund, Sweden \\ ${ }^{2}$ Max Planck Institute for Chemistry, Atmospheric Chemistry, Mainz, Germany \\ ${ }^{3}$ Leibniz Institute for Tropospheric Research, Leipzig, Germany \\ ${ }^{4}$ Royal Netherlands Meteorological Institute, de Bilt, The Netherlands \\ ${ }^{5}$ Institute for Meteorology and Climate Research, Karlsruhe Institute of Technology (KIT), Germany \\ Correspondence to: S. M. Andersson (sandra.andersson@ nuclear.lu.se)
}

Received: 12 April 2012 - Published in Atmos. Chem. Phys. Discuss.: 22 August 2012

Revised: 7 January 2013 - Accepted: 5 February 2013 - Published: 18 February 2013

\begin{abstract}
Large volcanic eruptions impact significantly on climate and lead to ozone depletion due to injection of particles and gases into the stratosphere where their residence times are long. In this the composition of volcanic aerosol is an important but inadequately studied factor. Samples of volcanically influenced aerosol were collected following the Kasatochi (Alaska), Sarychev (Russia) and also during the Eyjafjallajökull (Iceland) eruptions in the period 2008-2010. Sampling was conducted by the CARIBIC platform during regular flights at an altitude of $10-12 \mathrm{~km}$ as well as during dedicated flights through the volcanic clouds from the eruption of Eyjafjallajökull in spring 2010. Elemental concentrations of the collected aerosol were obtained by acceleratorbased analysis. Aerosol from the Eyjafjallajökull volcanic clouds was identified by high concentrations of sulphur and elements pointing to crustal origin, and confirmed by trajectory analysis. Signatures of volcanic influence were also used to detect volcanic aerosol in stratospheric samples collected following the Sarychev and Kasatochi eruptions. In total it was possible to identify 17 relevant samples collected between 1 and more than 100 days following the eruptions studied. The volcanically influenced aerosol mainly consisted of ash, sulphate and included a carbonaceous component. Samples collected in the volcanic cloud from Eyjafjallajökull were dominated by the ash and sulphate component ( $\sim 5 \%$ each) while samples collected in the tropopause region and
\end{abstract}

LMS mainly consisted of sulphate (50-77\%) and carbon (21-43\%). These fractions were increasing/decreasing with the age of the aerosol. Because of the long observation period, it was possible to analyze the evolution of the relationship between the ash and sulphate components of the volcanic aerosol. From this analysis the residence time (1/e) of sulphur dioxide in the studied volcanic cloud was estimated to be $45 \pm 22$ days.

\section{Introduction}

Despite its modest size, the eruption of Eyjafjallajökull volcano in the spring of 2010 caused considerable disruption of European air traffic due to the ash and sulphate aerosol it produced. In particular ash particles are hazardous, since they can damage jet engines and disrupt avionics and navigation systems (Casadevall, 1994), whereas sulphate aerosol have been reported to cause crazing of aircraft windows (Carn et al., 2009). Above all the complex effects of volcanoes on atmospheric chemistry and physics are also of concern for climate (Ammann et al., 2003). Not only the amount of ejected material, the location of the volcano and the force of the eruption, but also the properties of volcanic aerosol play a considerable role in these contexts. Unfortunately, our present understanding of the composition of volcanically influenced 
atmospheric aerosol is limited since quantitative measurements in the free troposphere and in the stratosphere are scarce. To improve this situation, we report here on the investigation of the elemental composition of volcanic aerosol sampled directly in the volcanic cloud from the Eyjafjallajökull eruption in 2010, and moreover sampled in the upper troposphere/lowermost stratosphere (UT/LMS) following eruptions of the volcanoes Kasatochi (Alaska, 2008) and Sarychev (Russia, 2009).

The scattering and absorbing properties of volcanic aerosol affect the Earth's radiation budget and thus result in temperature gradients that perturb circulation patterns and impact climate (IPCC, 2007). After the eruption of Mount Pinatubo in 1991, with a large Volcanic Explosivity Index (VEI) (Newhall and Self, 1982) of 6, the global, tropospheric temperature was estimated to have been $0.5^{\circ} \mathrm{C}$ lower than the climatological average temperature. Another large eruption in Tambora (1815, VEI 7) caused an estimated drop in global mean temperature of 0.4 to $0.7^{\circ} \mathrm{C}$ (McCormick et al., 1995). Stratospheric aerosols also act as surfaces for heterogeneous reactions that affect the distribution of ozone and other trace gases (IPCC, 2007). Not only massive eruptions such as those mentioned above are of importance to the stratospheric aerosol load. A study by Vernier et al. (2011) based on satellite observations shows that eruptions of lower explosivity are also an important source of stratospheric aerosol. Their effect is visible in the increase of the stratospheric aerosol layer that has occurred since 2002 after a period with little volcanic influence. This increase in the stratospheric aerosol load has also been observed in other data sets, however, anthropogenic influence cannot be ruled out (Hofmann et al., 2009; Solomon et al., 2011).

In the absence of volcanic eruptions, stratospheric aerosol is mainly found at altitudes of $20-30 \mathrm{~km}$ (Junge et al., 1961). This aerosol layer, referred to as the Junge layer, mainly consists of sulphate aerosol that is chiefly formed by sulphur dioxide $\left(\mathrm{SO}_{2}\right)$ produced from photo-dissociation of carbonyl sulphide (OCS) transported from the troposphere (Crutzen, 1976). However studies indicate that OCS is not enough to explain the observed aerosol load (Chin and Davis, 1995), and direct transport of $\mathrm{SO}_{2}$ or sulphate aerosol have been suggested as important contributions to stratospheric aerosol (Pitari et al., 2002; Myhre et al., 2004). Volcanic injections however makes it difficult to determine the background state of the stratospheric aerosol layer (Solomon et al., 2011), and thereby the importance of different sources for its production. A carbonaceous component of the UT/LMS aerosol was identified by Murphy et al. (1998), which was subsequently found to be a large fraction of the aerosol (Nguyen et al., 2008; Murphy et al., 2007). Martinsson et al. (2009) found that volcanic aerosol contains a large carbonaceous component. Additional sources contributing to the aerosol load in the UT/LMS, include air traffic (Ferry et al., 1999; Kjellström et al., 1999), meteorites (Cziczo et al., 2001) and boundary layer aerosol and precursor gases transported across the tropopause (Papaspiropoulos et al., 2002; Köppe et al., 2009). Especially aerosol from forest fires can be brought to high altitudes by extreme convection, however, the frequency and global contribution of such events is poorly understood (Fromm et al., 2004, 2008). Guan et al. (2010) estimated that on average about six such events per year lead to injection of particles to altitudes above $8 \mathrm{~km}$. With a frequency of one or a few events per year, volcanic eruptions contribute to stratospheric aerosol mass of similar magnitude as OCS does (Vernier et al., 2011), and in a few events per century volcanism is by far the strongest source of stratospheric aerosol (Ammann et al., 2003).

Volcanic eruptions inject large quantities of ash and gases into the atmosphere. Sulphur dioxide is the third most abundant gas in volcanic emissions, after water vapor and carbon dioxide (von Glasow et al., 2009). It is oxidized in the atmosphere thus leading to sulphate aerosol. Enhanced concentrations of stratospheric aerosol following the eruptions of El Chichón (1982) and Pinatubo (1991) had a residence time (1/e) of 10.3 and 12.0 months respectively (Jäger, 2005; Deshler, 2008). Especially the number concentration of particles larger than $1 \mu \mathrm{m}$ in diameter was observed to increase substantially following the Pinatubo eruption (Deshler, 2008). The directly emitted ash particles exhibit a size of $2 \mathrm{~mm}$ or less (by definition) (Heiken and Wohletz, 1985), and show a large span in size with particle diameters down to less than $1 \mu \mathrm{m}$ (Rose and Durant, 2009; Mather et al., 2003). Large particles sediment quickly while very fine ash particles $(<15 \mu \mathrm{m})$ have been found to have a residence time of days to weeks in the UT/LMS (Rose and Durant, 2009; Niemeier et al., 2009). During the first $24 \mathrm{~h}$ after an eruption a rapid decrease of the fine ash $(<25 \mu \mathrm{m})$ content of the volcanic cloud have been observed, likely caused by aggregation into larger particles with higher settling velocities (Rose et al., 2001). After this initial phase, ash concentrations decrease more slowly together with concentrations of $\mathrm{SO}_{2}$. Ash and $\mathrm{SO}_{2}$ clouds can either be travelling collocated or separated in the atmosphere. Vertical separation occurs due to the eruption style or by different sedimentation velocity of ash and $\mathrm{SO}_{2}$, and horizontal separation due to wind shear (Thomas and Prata, 2011). Although research has shown that fine ash particles are spread and deposited over large areas (Rose and Durant, 2009), we know little about the atmospheric fate (change in composition, lifetime) of volcanic particles in the micrometer size range.

Most research into atmospheric influence of volcanic eruptions is based on remote sensing from the surface or from satellite to follow the dispersal of volcanic $\mathrm{SO}_{2}$ clouds or to investigate the influence of eruptions on the stratospheric aerosol load. The actual composition of volcanic aerosol has been investigated by aircraft-based measurements by Martinsson et al. (2009) and Schmale et al. (2010) following the Kasatochi eruption in 2008 and recently by Schumann et al. (2011) in the volcanic cloud from Eyjafjallajökull. However these studies only consider aerosol composition from 
single eruptive events and do not address evolution of the composition of volcanic aerosol in the atmosphere. In the study by Martinsson et al. (2009) a subset of the data presented in this study was used to investigate the development of the sulphurous and carbonaceous components of the volcanically influenced aerosol.

Here we present and discuss the multi elemental composition of aerosol from three eruptions with VEI 4. The volcanic aerosol was collected between one and over 100 days after the eruptions, which provides a unique opportunity to investigate the evolution of the aerosol. Aerosol sampling and measurements of trace gases were performed by the CARIBIC (Civil Aircraft for Regular Investigation of the atmosphere Based on an Instrument Container) platform operating on a passenger aircraft (Brenninkmeijer et al., 2007; www.caribic-atmospheric.com).

\section{Experimental methods}

Samples of volcanic aerosol particles were obtained from the CARIBIC platform during regular long-distance passenger flights in the UT/LMS following large eruptions of the Kasatochi (2008) and Sarychev (2009) volcanoes, as well as during special flights at 4-12 km altitudes on 16 May and 19 May 2010, which were conducted to investigate the composition of the volcanic clouds produced by the Eyjafjallajökull eruption (Rauthe-Schöch et al., 2012). The CARIBIC measurement container is mounted in the forward cargo bay of a Lufthansa Airbus 340-600 during four sequential flights (Brenninkmeijer et al., 2007) on a monthly basis. From Frankfurt (Germany) destinations in North and South America, South Africa and South and East Asia are reached, thus covering a large geographical area mainly in the Northern Hemisphere. Instruments in the container automatically measure concentrations of many trace gases, aerosol number concentrations and the aerosol size distribution. In addition sampling of air and aerosol particles for laboratory analysis takes place. This study concentrates on volcanically influenced aerosol samples collected between 2008 and 2010, but also uses measurements of the background aerosol collected from 1999 to 2002 (Martinsson et al., 2005) and somewhat volcanically influenced samples from 2005 to 2008.

Aerosol particles of $0.08-2 \mu \mathrm{m}$ aerodynamic diameter were collected in a multi-channel aerosol sampler on $0.2 \mu \mathrm{m}$ thick polyimide foils (Nguyen et al., 2006) by impaction. The upper size limit is determined by a cyclone separator placed between the aerosol inlet and the sampler, and the lower limit by the cutoff diameter of the aerosol sampler. The sampler has 16 sampling channels with 14 for sequential collection and 2 for integral samples used to monitor contamination by comparing the integral samples to the sum of the sequential samples. The sampling time for each sequential sample is typically $100 \mathrm{~min}$, corresponding to a flight distance of approximately $1500 \mathrm{~km}$ at cruising speed, and a sampling vol- ume of approximately $0.25 \mathrm{~m}^{3} \mathrm{STP}$ (Standard Temperature $(273 \mathrm{~K})$ and Pressure $(1013 \mathrm{hPa}))$. Sampling is suspended when the outside pressure is above $350 \mathrm{hPa}$. However, during the special flights through the Eyjafjallajökull volcanic cloud, collection of aerosol at lower altitudes was allowed and the sampling time was reduced to $50 \mathrm{~min}$.

Aerosol samples were analyzed by accelerator-based techniques at the Lund ion beam analysis facility using two methods to obtain elemental concentrations: PIXE (ParticleInduced X-ray Emission) and PESA (Particle Elastic Scattering Analysis). In both methods the samples were mounted in a high vacuum chamber and irradiated with a beam of $2.55 \mathrm{MeV}$ protons. Concentrations of elements with atomic numbers of $16(S)$ or more were obtained by PIXE (Johansson and Campbell, 1988), and concentrations of hydrogen, carbon, nitrogen and oxygen by PESA (Nguyen and Martinsson, 2007). PESA was implemented for analysis of samples collected after 2005. Detection limits reached from several down to $0.1 \mathrm{ng} \mathrm{m}^{-3} \mathrm{STP}$, depending on element. The accuracy for elemental determination by both methods is estimated to be $10 \%$ (Nguyen and Martinsson, 2007). The PIXE technique can also detect silicon $(\mathrm{Si})$ when the concentrations are high, such as in aerosol samples which are dominated by aerosol particles from volcanic eruptions. In samples with low concentrations of $\mathrm{Si}$ problems arise due to interference with sulphur, which is often dominant. In samples with a $\mathrm{S} / \mathrm{Si}$ ratio below a critical value, these effects have been corrected for, but for larger $\mathrm{S} / \mathrm{Si}$ ratios corrections were not possible and the measured Si concentrations were excluded from the results. Elements that usually are below the detection limit $(\mathrm{Sr}, \mathrm{Zr})$ were detectable in samples collected in the Eyjafjallajökull volcanic clouds, using longer than usual analysis times.

We further use data from ozone measurements performed by two instruments on the CARIBIC platform. A UVphotometer is used for accurate determination of the ozone concentration by absorption of UV light and also serves as a standard for a fast chemiluminescence detector which enables ozone detection with high temporal resolution. The accuracy is estimated to be $0.3-1 \%$ at typical mixing ratios at a measurement frequency of $10 \mathrm{~Hz}$ (Zahn et al., 2012).

Also measurements of $\mathrm{SO}_{2}$ concentrations and particle size distributions during the flights in the volcanic cloud from Eyjafjallajökull were used in this study. Concentrations of $\mathrm{SO}_{2}$ are obtained from the CARIBIC DOAS (Differential Optical Absorption Spectroscopy) instrument (Dix et al., 2009), detecting $\mathrm{NO}_{2}, \mathrm{HCHO}, \mathrm{HONO}, \mathrm{BrO}, \mathrm{OClO}, \mathrm{O}_{3}, \mathrm{SO}_{2}$ and $\mathrm{O}_{4}$ simultaneously by measuring scattered or reflected sunlight, collected with three telescopes pointing to $-82^{\circ}$, $-10^{\circ}$ and $+10^{\circ}$ relative to the horizon, with a temporal resolution of $8 \mathrm{~s}$. During the volcanic flights the instrument was only functioning properly on May 16 , measuring in the $-82^{\circ}$ and $-10^{\circ}$ directions (Heue et al., 2011). Particle size distributions are measured with an integrated OPC (Optical Particle Counter), which measures particles with a diameter in the 


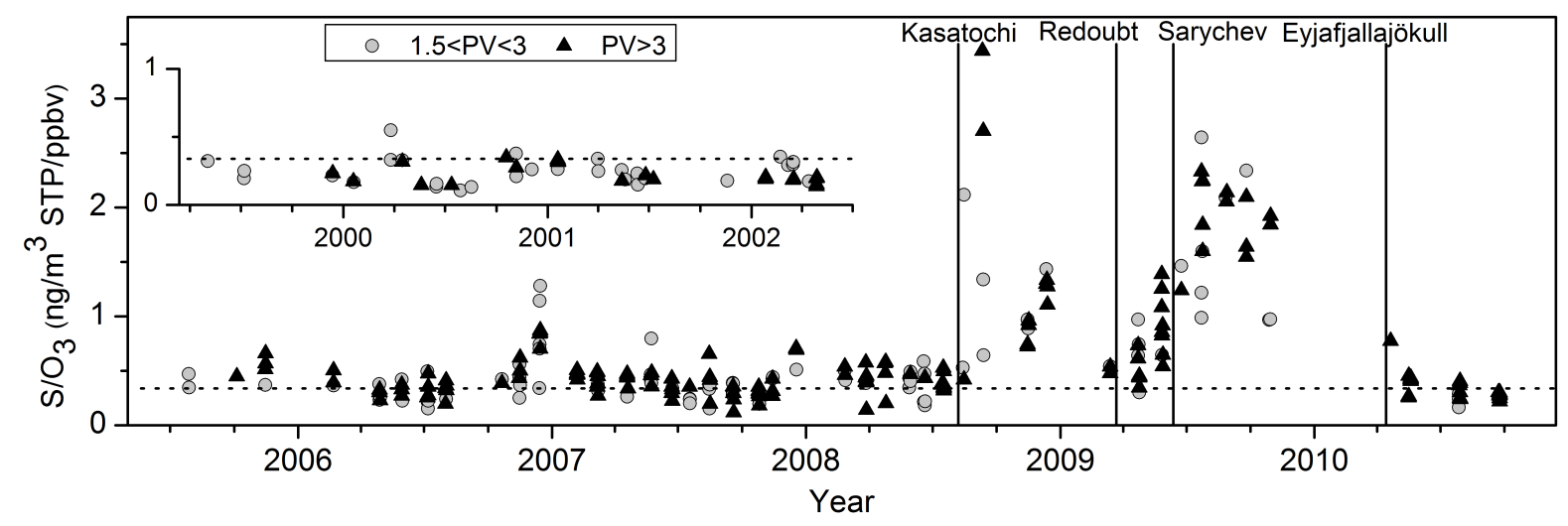

Fig. 1. Ratio of particulate sulphur to ozone concentration in aerosol samples collected in the tropopause region (grey circles) and the lowermost stratosphere (black triangles). The dotted line indicates the geometrical mean of samples collected before the eruption of Kasatochi in August 2008. The occasions of major eruptions are marked by vertical lines.

range of approximately $0.1-1 \mu \mathrm{m}$. OPC measurements from the volcanic flight on 19 May were used in this study (Heue et al., 2011; Rauthe-Schöch et al., 2012). A time resolution of 3 min was used to calculate the OPC size distributions during this flight.

Potential vorticity (PV) at the location of the aircraft was used to determine whether collected particles were of tropospheric or stratospheric origin, the tropopause region was defined as the region between 1.5-3 PVU (Potential Vorticity Unit; $\left.1 \mathrm{PVU}=10^{-6} \mathrm{~K} \mathrm{~m}^{2} \mathrm{~kg}^{-1} \mathrm{~s}^{-1}\right)$. PV was derived from archived ECMWF (European Centre for Medium-range Weather Forecast) analyses with a resolution of $1 \times 1$ degree in the horizontal direction and 91 vertical hybrid sigmapressure model levels. To obtain PV at the aircraft position the PV values was interpolated linearly in latitude, longitude, $\log$ pressure and time for each sample.

The recent history of probed air was investigated by means of 5-days backward air mass trajectories, calculated every third minute along the flight route using the trajectory model TRAJKS (Scheele et al., 1996) and the horizontal and vertical wind fields provided by ECMWF.

Complementary to trajectory analysis, lidar measurements from the CALIPSO (Cloud-Aerosol Lidar and Infrared Pathfinder Satellite Observations) satellite were used. The lidar is equipped with a Nd:YAG laser producing highly polarized co-aligned beams with wavelengths of 532 and $1064 \mathrm{~nm}$. Clouds and different types of aerosol particles can be identified since the shape and size of particles and droplets cause different scattering properties at these wavelengths (Winker et al., 2009).

\section{Results}

\subsection{Identification of volcanic aerosol}

A first indication of volcanic influence on CARIBIC UT/LMS aerosol samples is high concentrations of sulphur. These concentrations correspond to sulphate aerosol produced from $\mathrm{SO}_{2}$ emitted during eruptions. Such influence is mainly seen in stratospheric samples, where the residence time of aerosol particles is long compared to the troposphere. In Fig. 1 the ratio of $\mathrm{S} / \mathrm{O}_{3}$ is used as an indicator of volcanic influence on stratospheric aerosol. Concentrations of $\mathrm{S}$ and $\mathrm{O}_{3}$ show a correlation in absence of volcanic influence, since both sulphate and ozone are produced in the stratosphere with the aid of shortwave radiation. Consequently, high concentrations of sulphur are usually observed in association with downward transport in the stratosphere, together with elevated $\mathrm{O}_{3}$ levels (Martinsson et al., 2009). Explosive volcanic eruptions disturb this ratio by injecting large amounts of additional sulphur. In Fig. 1, volcanic influence is indicated by elevated $\mathrm{S} / \mathrm{O}_{3}$ ratios following major eruptions (VEI 4) of the Kasatochi $\left(52.18^{\circ} \mathrm{N}, 175.51^{\circ} \mathrm{W}\right.$, August, 2008), Redoubt (60.49 ${ }^{\circ} \mathrm{N}, 152.74^{\circ} \mathrm{W}$, March/April, $2009)$ and Sarychev $\left(48.09^{\circ} \mathrm{N}, 153.20^{\circ} \mathrm{E}\right.$, June, 2009) volcanoes. The sulphurous and carbonaceous components of the aerosol related to the Kasatochi eruption were discussed in detail in the study by Martinsson et al. (2009). Fig. 1 shows that elevated $\mathrm{S} / \mathrm{O}_{3}$ ratios prevailed for at least four months after the Kasatochi eruption and were just reaching background levels when elevated concentrations of sulphur again were observed after the Redoubt and Sarychev eruptions in 2008. The small effects of the Eyjafjallajökull $\left(63.63^{\circ} \mathrm{N}, 19.62^{\circ} \mathrm{W}\right)$ eruption in April/May 2010 can be explained by the fact that the emissions were poor in $\mathrm{SO}_{2}$ and that only a small fraction of the plume reached the stratosphere (BGVN, 2010; Thomas and Prata, 2011). However, 


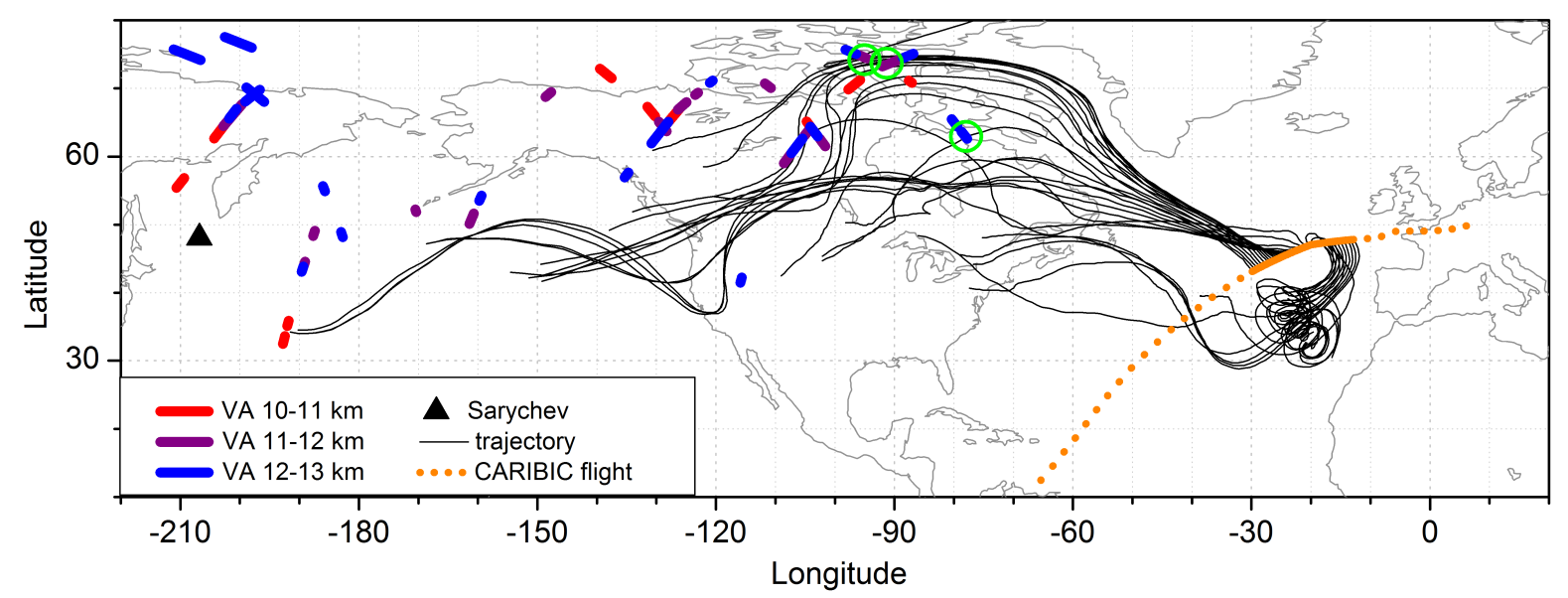

Fig. 2. Air-mass back-trajectories (thin black lines) calculated for one sample collected during the first CARIBIC flight from Frankfurt to Caracas at 23 June 2009 (orange dotted line) following the eruption of Sarychev, combined with volcanic aerosol (VA) layers at 10-13 km altitude (colored lines) obtained from CALIPSO lidar measurements at 21 June 2009. Green circles indicate where trajectories and aerosol layers intersect horizontally and vertically.

very high concentrations of crustal elements were found in three aerosol samples collected during the special flights on 16 May and 19 May 2010, strongly indicating volcanic influence. These samples were collected in the troposphere and are thus not included in Fig. 1, which only shows samples collected in the stratosphere or the tropopause region.

Further connection to the eruptions was established by using 5-days, and in one case 8-days, backward trajectory analysis for samples following the Kasatochi (Martinsson et al., 2009), Sarychev and Eyjafjallajökull eruptions. The first samples following the eruption of Redoubt were collected more than a month after the first explosion; hence trajectory analysis could not be used to verify volcanic origin. In addition, these samples show less elevation in their $\mathrm{S} / \mathrm{O}_{3}$ ratio than the samples following Sarychev and Kasatochi. The eruptions of Sarychev and Kasatochi emitted approximately 1.2 Tg (Haywood et al., 2010) and $2 \mathrm{Tg}$ (Yang et al., 2010) of $\mathrm{SO}_{2}$, respectively, into the atmosphere which can be compared to only $0.08 \mathrm{Tg}$ by the eruption of Redoubt (Lopez et al., 2009). It is thus unlikely that the sulphate aerosol produced by the Redoubt eruption had large enough influence for a clear identification in sampled aerosol. It is possible that the elevated concentrations in the samples instead are due to downward transport of an upper branch of the aerosol produced in the preceding eruption of Kasatochi. The volcanically influenced aerosol also contains a crustal component, which will be further discussed in Sect. 3.2. Stratospheric concentrations of crustal elements such as potassium (K) and iron $(\mathrm{Fe})$ show a seasonal dependence with high concentrations in spring (March to June) that seem to be connected with transport across the tropopause from the troposphere (Martinsson et al., 2005). The samples collected following the Redoubt eruption were collected at this time of the year; therefore it cannot be excluded that the crustal component of the aerosol has been transported from the boundary layer rather than been injected by the eruption. Due to the uncertainty of the source of the aerosol following the Redoubt eruption, these samples are excluded from further consideration.

Trajectory analysis performed for each of the three samples with large crustal components from the Eyjafjallajökull volcanic clouds showed that the sampled air had passed over the volcano. The transport time from the volcano to the aircraft position, and thus the age of the aerosol, was estimated to have been about 40 and $45 \mathrm{~h}$ for the samples collected May 16 and about $25 \mathrm{~h}$ for the sample collected May 19. The time for sampling within the volcanic cloud, and thereby the most likely transport path, was determined from peaks in the $\mathrm{SO}_{2}$ and particle mass concentrations obtained from the CARIBIC DOAS and OPC instruments (Heue et al., 2011; Rauthe-Schöch et al., 2012).

Trajectory analysis conducted for samples following the Sarychev eruption was combined with lidar measurements from CALIPSO (Fig. 2). The large amount of sulphate produced during this eruption made it possible to follow the volcanic aerosol in the lidar measurements up to more than a month after the eruption. Aerosol layers detected by CALIPSO at an altitude between 10 and $13 \mathrm{~km}$ were identified, and this information was put together with the path of calculated air mass trajectories. By this method aerosol produced in the eruption earlier than the 5 days backward time span of the trajectories could be linked to the eruption, by investigating if the trajectories intersected these aerosol layers. Three samples collected during the first flight after the Sarychev eruption, taking place 12 days after the start of the eruption, had trajectories that clearly traversed aerosol layers. 


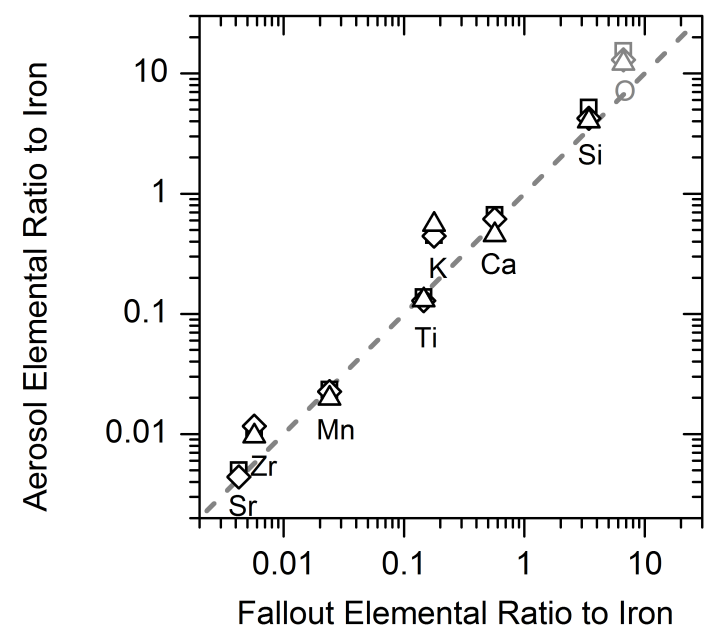

Fig. 3. Elemental ratio to iron in three aerosol samples (shown by different symbols) collected by the CARIBIC platform vs. fall out sample (SRG 5a, Sigmundsson et al., 2010). The dashed line indicates equal ratio. The oxygen content in the fallout sample is not measured and therefore indicated by grey symbols (see text for futher details).

Also samples collected during the next flight, 6 weeks after the eruption, could be connected to the aerosol produced in the eruption by this method, because the volcanic cloud could still be identified in the CALIPSO measurements.

\subsection{Ash composition}

The high concentrations of crustal elements in three of the samples collected during the Eyjafjallajökull eruption are important indications of volcanic origin. To further investigate this component of the aerosol it was compared to the composition of a fall-out sample of volcanic ash from the eruption site (Sigmundsson et al., 2010). The composition of erupted material can change over time and also with distance from the source due to fractionation and sedimentation (Carey and Sigurdsson, 1982). Thus it is not obvious that the fall out sample should be representative of the ash composition in the aerosol sample. Interestingly the composition for the three CARIBIC samples shows good agreement with the fallout sample for crustal elements (Fig. 3). Only the concentrations of potassium (K) and Zirconium (Zr) show some larger deviations. One explanation to the higher aerosol potassium $(\mathrm{K})$ content in the CARIBIC samples could be fractioning in concentration between different sizes of ash particles in the samples analyzed, due to a larger surface area to mass ratio of small particles. Small ash particles remain in the plume longer than larger particles, and cool faster, which favors condensation of volatiles onto the smaller particles (Witham et al., 2005). Among the elements presented in Fig. 3, K happens to be the most volatile species found enriched in volcanic gases, due to degassing from the magma (Hinkley et al., 1994; Rubin, 1997). Also Zr was found in enhanced con- centrations in deposits from a volcanic plume compared to the magma (Moune et al., 2005), indicating that also this element could have been abundant in the gas phase and condensed onto the ash particles.

The oxygen content (corrected for the amount of oxygen assumed bound to sulphurous aerosol in the form of sulphate) is also high compared to that of the fallout sample. The amount of oxygen in the fallout sample was not measured (indicated by grey symbols in Fig. 3), but are expressed as generalized oxygen proportions to the corresponding elements. It should however represent the approximate oxygen content, indicating that there is more oxygen in the aerosol samples. A likely explanation for the extra oxygen is that part of it is bound to the carbonaceous fraction of the aerosol (see Sect. 3.3).

The ash component of the Eyjafjallajökull aerosol is also similar to Earth's crustal composition (Rudnic and Fountain, 1995). Although analysis of rare elements such as the chalcophile metals $(\mathrm{Bi}, \mathrm{Cd}, \mathrm{Cu}, \mathrm{In}, \mathrm{Pb}$ and $\mathrm{Tl})$, found in volcanic plumes from degassing of silicate melts (Hinkley et al., 1994), would be necessary to distinguish volcanic ash from this type of source, the high concentrations of crustal elements together with elevated sulphur concentrations in the aerosol samples are strong evidence of volcanic origin. On a final note, all of the elements, except manganese (Mn), in these three samples have the highest concentrations noted in the entire CARIBIC data set taken over a 10 years period. Therefore the composition of crustal elements in the Eyjafjallajökull aerosol samples (Fig. 3) is used here to define the ash component of volcanic aerosol.

The ash component of the sampled aerosol caused by the Kasatochi and Sarychev eruptions was identified by comparing it to the ash composition of the Eyjafjallajökull samples, as no fallout samples were available from these eruptions. Since this composition cannot be clearly distinguished from Earth's crustal composition, it was used as an indicator of volcanic ash in those samples with elevated $\mathrm{S} / \mathrm{O}_{3}$ levels, and for early collected samples, where trajectory analysis indicate volcanic origin. In addition the identified samples from the Kasatochi and Sarychev eruptions were collected in the summer to winter period when little influence of crustal particles in the LMS is seen (Martinsson et al., 2005). Only the three first samples following the Sarychev eruption were collected in spring when concentrations are usually elevated. For these samples however there is strong evidence of volcanic influence from the trajectory analysis and aerosol composition. Also meteoritic material can contribute to elements indicative of crustal material. Samples which are mainly influenced by meteorites can be identified by their $\mathrm{Fe} / \mathrm{Ni}$ ratio (Kopp, 1997), which was used to exclude them from this study.

In Fig. 4 we include all samples having a crustal component classified to be of volcanic origin. These samples have a geometric residual sum of squares (RSS) in their elemental to iron ratios of less than two compared to the geometric mean 

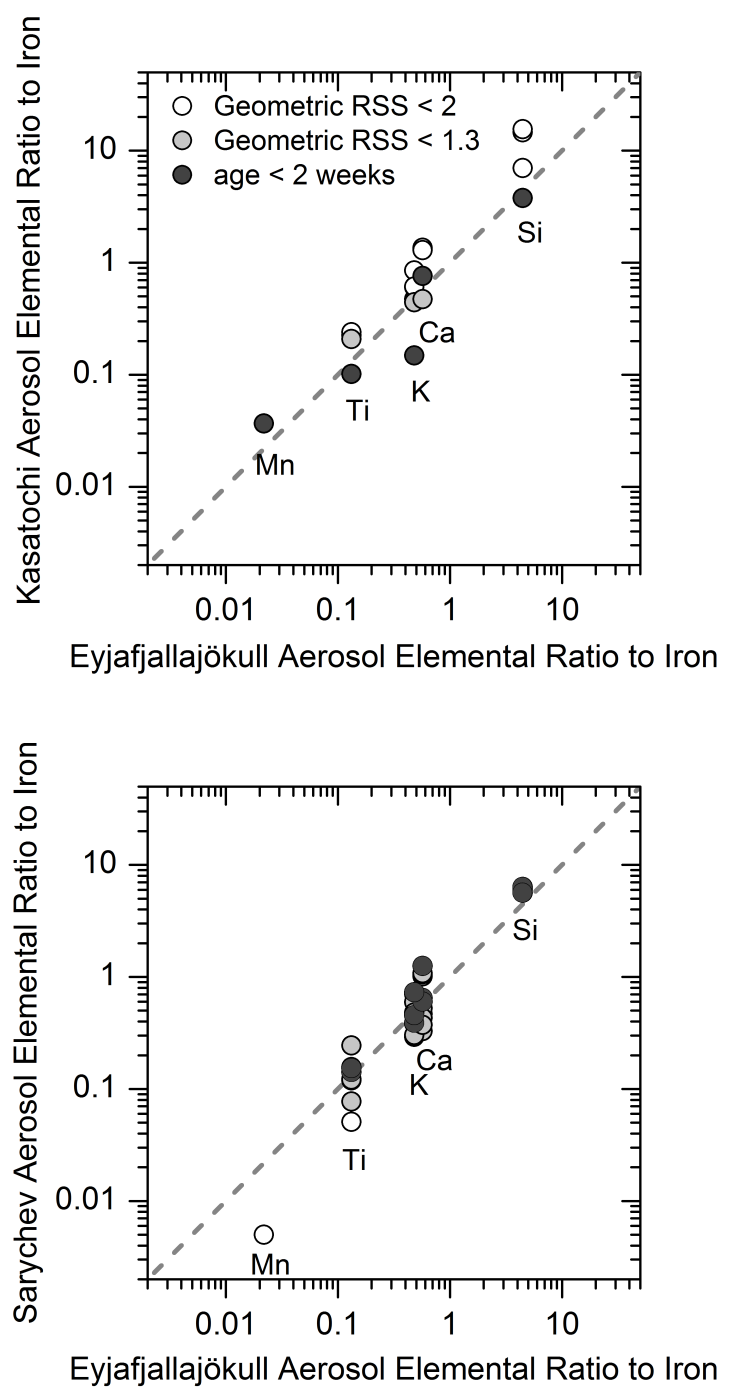

Fig. 4. Elemental ratio to iron in aerosol samples collected following eruptions of Sarychev and Kasatochi vs. geometric mean of volcanic aerosol collected in the volcanic cloud from Eyjafjallajökull. The dashed line indicates equal ratio. Samples with a Residual Sum of Squares (RSS) of less than two are included in the figures. Samples collected less than two weeks after the start of the eruptions are marked by dark circles.

of the Eyjafjallajökull aerosol samples (shown in Fig. 3). A minimum limit of at least three detected elements was applied to be able to examine the composition. Also the detection limit of undetected elements in relation to the iron content was taken into account. Samples were excluded if more than one of the elements $\mathrm{K}, \mathrm{Ca}$, Ti or Mn were missing even though they were expected to have had a concentration above the detection limit in relation to the content of $\mathrm{Fe}$ in the samples. One missing element was accepted to account for the risk of contamination due to mixing in the atmosphere and since it is likely that the composition of ash from different eruptions is not exactly the same. The ash composition depends on the magma type as well as on the absorption of volatiles onto the ash particles which is controlled by a number of factors such as eruption type, concentration of gases and particles and particle size (Witham et al., 2005). As can be seen from Fig. 4, $\mathrm{Si}$ is only represented in a few samples which is due to problems with interference with $S$ as described in Sect. 2. Also Mn is represented only in a few samples since its concentrations in ash is low hence falling below the detection limit in samples of low ash content.

The composition of samples collected 8 days after the Kasatochi eruption and 12 days after the Sarychev eruption (indicated by dark circles in Fig. 4) show good agreement with the composition of the Eyjafjallajökull sample, except for lower concentrations of $\mathrm{K}$ in the sample from the Kasatochi eruption. Also samples collected one month or more after the eruptions are similar in their composition but ratios show more scatter. The larger deviations in composition in these samples indicate that the aerosols are more mixed and influenced by other sources. In addition changed emissions during the eruptions can cause variations in the composition of ash. The identified samples, classified as volcanic aerosol both by elevated $\mathrm{S} / \mathrm{O}_{3}$ ratios and composition of the crustal (ash) component, range in age between 8 to 128 days and 12 to 77 days from the start of the explosive phase of the Kasatochi and Sarychev eruptions, respectively. The length of these eruptions adds an uncertainty to these age estimates ( 1 and 5 days of explosive eruptions in the case of Kasatochi and Sarychev, respectively, BGVN, 2009; Waythomas et al., 2010).

\subsection{Carbonaceous aerosol in volcanic clouds}

The aerosol in volcanic clouds studied here contains a large fraction of carbonaceous aerosol. This has earlier been observed following the eruption of Kasatochi (Martinsson et al., 2009; Schmale et al., 2010) and in fresh volcanic clouds (Carn et al., 2011). A carbonaceous aerosol component has been observed in volcanic clouds from several volcanoes despite the fact that only for few volcanos lava can interact with carbonates in the crust prior to eruption. The volcanoes considered here do not belong to this category. This is corroborated by the measurements because the stoichiometric relations between carbon, oxygen, sulphur and ash elements in the sampled aerosol do not permit such an oxygen-rich form of carbon. Therefore explanations other than direct volcanic emissions need to be considered. One common source of carbonaceous material is combustion. Pyro-convection during forest fires can inject particles into the UT/LMS. However such events are not frequent and none one of the events identified in Guan et al. (2010) coincides with the eruptions studied here. Also no clearly elevated concentrations of $\mathrm{K}$ in excess of the ash concentration are seen in the samples, which would be expected from fires (Andreae et al., 1998). One 
alternative explanation is the carbon content of the air that is entrained into the volcanic jet and lifted with the volcanic effluents. Mixing with air creates the buoyancy needed for the formation of a volcanic plume that can reach the stratosphere (Suzuki and Koyaguchi, 2010).

To obtain an estimate on the organic aerosol concentration in the region of the volcanoes studied, we consider the conditions in the boundary layer, where large numbers of observations are available. Boundary layer air contains high concentrations of carbonaceous aerosol from anthropogenic and from natural sources. Jimenez et al. (2009) report average urban organic aerosol concentrations up to $30000 \mathrm{ng} \mathrm{m}^{-3}$ (Beijing, China) and, even at remote sites like Hyytiala, Finland the organic concentration exceeds one thousand $\mathrm{ng} \mathrm{m}^{-3}$. In a study focusing on the USA, urban regions average concentrations of several thousand $\mathrm{ng} \mathrm{m}^{-3}$ were found and in rural areas the organic concentration was of the order $1000 \mathrm{ng} \mathrm{m}^{-3}$ (Hand et al., 2012). Interestingly, the Alaskan rural average organic aerosol concentration peaks in August, the month of the Kasatochi eruption, at approximately $3000 \mathrm{ng} \mathrm{m}^{-3}$. Organic aerosol sources extend also to the oceans. Regional and seasonal variation in oceanic biological activity can be derived from SeaWiFS sensor on the OrbView2 satellite. The activity shows strong geographical and seasonal variations (Stramska, 2009). Measurements in Maze Head (Ireland) show organic aerosol concentration of several hundred $\mathrm{ng} \mathrm{m}^{-3}$ connected with biologic activity in the ocean during spring to autumn (O'Dowd et al., 2004; Yoon et al., 2007). All three volcanoes studied here erupted in the biologically active part of the year. Modelling of the global distribution of yearly average organic aerosol with the ocean source included indicate high, to a large degree ocean-derived, organic aerosol concentration over the ocean surrounding island volcanoes Sarychev, Kasatochi and Eyjafjallajökull. For Sarychev a concentration of approximately $1000 \mathrm{ng} \mathrm{m}^{-3}$ was obtained, the same or somewhat lower for Kasatochi and a few hundred $\mathrm{n} \mathrm{m}^{-3}$ for Eyjafjallajökull (Spracklen et al., 2008). Additional organic material can be derived from gaseous precursors. Influence of volcanic halogen emissions on organic chemistry is important in the often $\mathrm{OH}$ poor volcanic clouds (von Glasow et al., 2009). In the volcanic cloud of Eyjafjalljökull chlorine radicals rapidly depleted organic trace gases to levels well below background concentrations (Baker et al., 2011). Such processes can further add particulate carbon to the volcanic cloud. The LMS particulate carbon concentration measured by CARIBIC outside directly injected volcanic clouds is approximately $100 \mathrm{ng} \mathrm{m}^{-3}$ at STP. In volcanic clouds the concentration typically is a few hundred $\mathrm{ng} \mathrm{m}^{-3} \mathrm{STP}$, reaching more than one thousand $\mathrm{ng} \mathrm{m}^{-3}$ STP in three observations of the volcanic cloud from Sarychev. The regional average particulate carbon concentrations in the boundary layer around the volcanoes studied here are thus comparable to the observations at high altitude (free troposphere, UT and LMS) in this study. Although sources in direct connection to the
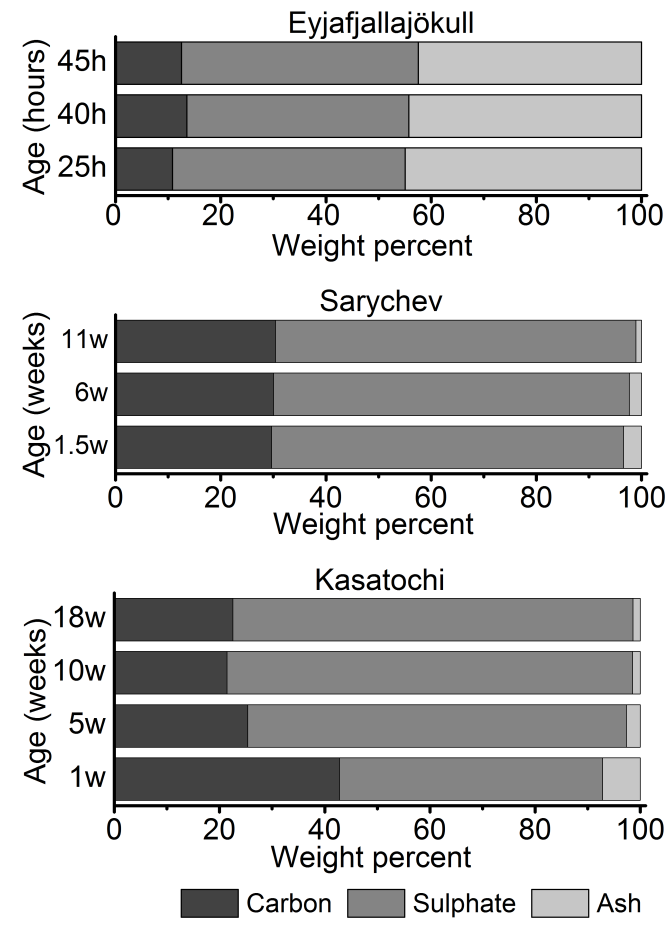

Fig. 5. Major components of aerosol samples collected following eruptions in Eyjafjallajökull, Sarychev and Kasatochi. Aerosol collected 1.5, 6 and 11 weeks after the eruption in Sarychev are shown as averages of 3, 6 and 2 samples respectivley. The composition of aerosol collected 18 weeks after the Kasatochi eruption are an average of 3 samples. The remaining aerosol compositions are each represented by only one sample. The carbonaceous fraction is averaged over all samples of the aerosol from Sarychev, see text for further details.

volcano, such as burning vegetation and sedimentary layers, also could contribute to carbonaceous aerosol, we hypothesize that organic material in entrained air constitutes a significant fraction of the particulate carbon observed in volcanic clouds.

\subsection{Major components}

The main components of the samples classified as volcanic aerosol are carbon, sulphate and ash (Fig. 5). Samples influenced by Kasatochi and Sarychev are grouped with respect to age, where the compositions of aerosol collected at approximately the same time from the eruptions (i.e. from the same CARIBIC flight sequence) are presented as mean values. The carbonaceous component is presented as the mass of the measured carbon concentrations, since the stoichiometry of the carbon aerosol is unknown. The mass of sulphate $\left(\mathrm{SO}_{4}\right)$ was calculated by adding the amount of oxygen corresponding to the measured mass of sulphur, assuming that all sulphur is in the form of $\mathrm{SO}_{4}$. In a similar manner the mass of the ash components in the Eyjafjallajökull samples were obtained by adding the mass of oxygen according to the fallout 
sample presented in the table by Sigmundsson et al. (2010). Elements found in ash that could not be detected, primarily sodium $(\mathrm{Na})$, magnesium $(\mathrm{Mg})$, aluminum $(\mathrm{Al})$ and phosphorus $(\mathrm{P})$, were calculated according to the composition of the fallout sample using the relation to the iron content. The entire ash components of samples influenced by the Sarychev and Kasatochi eruptions were estimated based on their $\mathrm{Fe}$ content since many of the elements were below their detection limits. In these samples the mass of $\mathrm{Fe}, \mathrm{S}$ and $\mathrm{C}$ was corrected for stratospheric background concentrations calculated as averages of samples with concentrations below the 95 percentile collected during the period from 1999 to the eruption of Kasatochi in August 2008. For S and C this correction was done with respect to the $\mathrm{O}_{3}$ mixing ratios measured during the sampling time since they show a correlation with $\mathrm{O}_{3}$. For $\mathrm{Fe}$, the background correction was done with respect to season, divided into December-February, June-August and September-November (no samples were obtained in the period March-May). Since the samples from the Eyjafjallajökull eruption originate in lower altitudes than the CARIBIC platform usually measures, no such correction was made for them. Therefore $\mathrm{C}$ and $\mathrm{S}$ components should be considered to represent maximum estimates. However the concentrations were very high so the background influence most likely was small.

Figure 5 reveals that the samples collected following Eyjafjallajökull's eruption show little variation in their compositions, they mainly consist of ash and sulphate in about equal amounts. In contrast samples influenced by the eruptions of Kasatochi and Sarychev to a large extent consist of sulphate and carbon, while the ash component is well below $10 \%$. Even though the carbon and sulphate components comprise a smaller part of the mass in the Eyjafjallajökull samples compared to them influenced by the other two volcanoes, the respective concentrations are of similar magnitude as in the Kasatochi and Sarychev samples, while the ash component is approximately a factor of 10 higher in the Eyjafjallajökull samples.

The aerosol from Sarychev shows a strong dependence of the carbon-to-sulphur ratio on latitude, with increasing $\mathrm{C} / \mathrm{S}$ ratio with increasing latitude, while the iron-to-sulphur ratio shows no such dependence (not shown). Possibly changing properties of the eruptions that persisted for several days and/or differences in carbonaceous aerosol precursor gases combined with transport patterns from the source could explain this latitudinal dependence. The time evolution of $\mathrm{C}$ can thus not be given. Instead the average $\mathrm{C} / \mathrm{S}$ over the volcanically influenced samples taken from June to October 2009 was used to obtain the C component for Sarychev in Fig. 5. A decreasing fraction of ash with time is observed from Sarychev. The aerosol from the Kasatochi eruption has a simpler C-to-S relation. The sulphurous fraction shows an increase with time, whereas the ash and carbonaceous fractions decline.

\subsection{Effects of sedimentation and coagulation on the composition evolution}

Figure 5 shows that there is a change in the relations of the components of the Kasatochi and Sarychev volcanic aerosol with its age. The relative increase of $\mathrm{SO}_{4}$ is likely caused by the transformation of $\mathrm{SO}_{2}$ into $\mathrm{SO}_{4}$ particles. Also higher rates of removal of ash (and C) might contribute to the observed pattern. Since all samples older than two weeks were taken in the stratosphere or the tropopause region, where little wet scavenging occurs, the solubility of the particles had no or only a small influence on the rate of deposition. The impact of different sedimentation rates of ash and $\mathrm{SO}_{4}$ particles was investigated by estimating their settling velocity. In the computations the particle diameters that carry most of the mass according to the particle mass distributions were applied. For the sulphate particles, spherical droplets of sulphuric acid solution with a diameter of $0.6 \mu \mathrm{m}$ (Martinsson et al., 2005) (corresponding to $0.76 \mu \mathrm{m}$ aerodynamic diameter) and a density of $1600 \mathrm{~kg} \mathrm{~m}^{-3}$ (Yue et al., 1994) were used in the calculations. The diameter of the sulphate aerosol estimated by Martinsson et al. (2005) was obtained from the effective radius of stratospheric aerosol from lidar observations (Bauman et al., 2003) during a period with low volcanic activity. Thus the radius is underestimated for volcanic aerosol which usually exhibit larger diameters (Bauman et al., 2003; Deshler et al., 2003). Ash particles usually have substantially larger diameters (Schumann et al., 2011). The $2 \mu \mathrm{m}$ aerodynamic diameter upper size limit of the aerosol sampler was thus used to estimate the upper limit in settling velocity of the ash. The thickness of the volcanic aerosol layers from the Sarychev and Kasatochi eruptions, through which the volcanic aerosol has to settle, was estimated by locating the altitude of volcanic aerosol during the first week after the eruptions using CALIPSO lidar measurements. After some time the identified volcanic aerosol layers are assumed to have been horizontally mixed and contributed to a more or less homogeneous aerosol layer. Therefore a cumulative altitude distribution of the volcanically influenced air from $10 \mathrm{~km}$ altitude and upwards was calculated, by summing all events when volcanic aerosol was observed at a certain altitude, see Fig. 6. According to the above method about $85 \%$ of the identified aerosol following the Sarychev eruption was injected to a height between 10 and $15 \mathrm{~km}$. Therefore a $5 \mathrm{~km}$ thick layer was assumed to have been produced. The aerosol layer formed by the Kasatochi eruption was less homogenous with $75 \%$ of the aerosol located between $10-13 \mathrm{~km}$ and the remaining aerosol extending up to $\sim 20 \mathrm{~km}$. During the 2 months we followed these volcanic clouds, the $2 \mu \mathrm{m}$ ash particles fall a distance of about $10 \%$ of the thickness of the volcanic aerosol layer produced by Sarychev and about $17 \%$ of the lowest $3 \mathrm{~km}$ of the volcanic aerosol produced by Kasatochi. Since the aerosol samples were collected in the lower part of these layers, at $10-11.3 \mathrm{~km}$, there should thus still be large amounts of $2 \mu \mathrm{m}$ ash particles, originating in the 


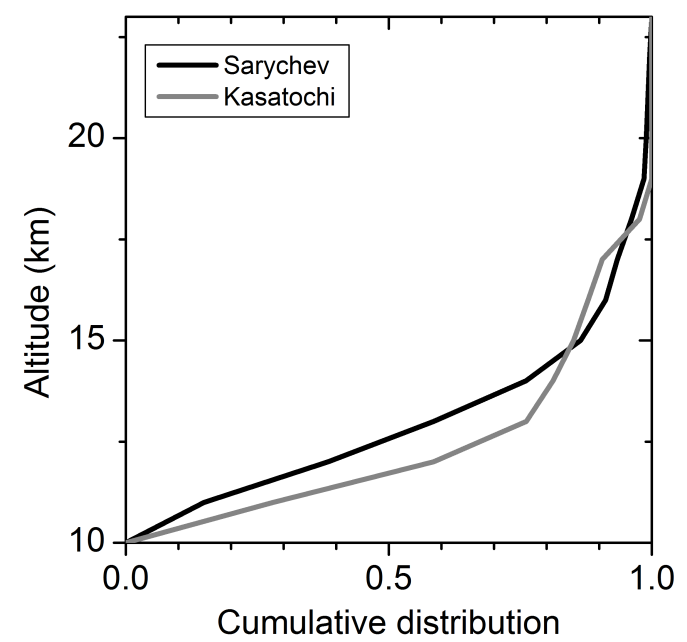

Fig. 6. Cumulative altitude distributions of volcanic injections above $10 \mathrm{~km}$ the first week after the Sarychev and Kasatochi eruptions. The distributions was deduced from the number of observations of volcanic aerosol layers in CALIPSO lidar measurements as a function of altitude, see the text for further details.

upper part of the volcanic aerosol layers. Bearing in mind that the sulphate sedimentation was underestimated and that of ash was overestimated, this simple estimation suggests that the difference in deposition velocity between ash and sulphate particles only has minor importance for the relation between the measured ash and sulphate concentrations on the timescale considered here.

In addition, coagulation of particles needs to be considered as it can enhance the sedimentation velocity and can grow particles to diameters outside the collection range of the sampler. However the paticle concentrations in samples collected more than one week after the Kasatochi and Sarychev eruptions are low, $\sim 22 \mathrm{ng} \mathrm{m}^{-3}$ ash and $\sim 156 \mathrm{ng} \mathrm{m}^{-3} \mathrm{SO}_{4}$ in the first sample collected following the Kasatochi eruption. Calculations based on thermal coagulation (Hinds, 1999), points to that the effects of particle coagulation is very small in the concentrations encountered in these volcanic clouds. In order to simplify the estimates of coagulation, the case of monodispersed ash and sulphate particles of the same properties as described for the sedimentation calculations were used. The resulting change in the number concentration both from coagulation of ash and of sulphate particles is less than $1 \%$ during the 2 months considered. Coagulation thus is estimated to be of minor importance because the aerosol concentrations in the observed clouds are too low for that process to be efficient.

\subsection{Sulphur dioxide conversion rate in volcanic clouds}

To further evaluate the evolution of the volcanic aerosol the sulphate and ash components were studied more in detail. In Fig. 7 the ratio of $\mathrm{Fe} / \mathrm{S}$ shows the relation between the

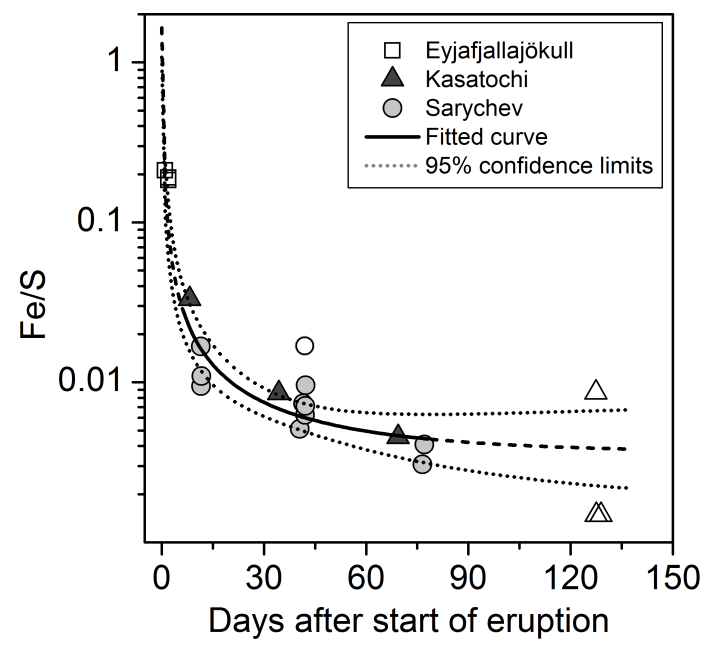

Fig. 7. Mass ratio of iron to sulphur in aerosol samples influenced by three volcanoes (marked by different symbols) vs. time since the start of the eruptions. The line shows a fit to the Fe/S ratio for the samples influenced by the Sarychev and Kasatochi eruptions. Samples shown with open symbols have been excluded from the fit.

ash and sulphate components as a function of time after the eruptions. As the difference in sedimentation velocity of ash and sulphate particles in the $0.08-2 \mu \mathrm{m}$ size range were estimated to be of small importance, the decreaseing trend of $\mathrm{Fe} / \mathrm{S}$ is likely explained by the conversion rate of $\mathrm{SO}_{2}$ into sulphate aerosol. The residence time of $\mathrm{SO}_{2}$ can thus be estimated from the decrease in the $\mathrm{Fe} / \mathrm{S}$ ratios. From the reaction of $\mathrm{SO}_{2}$ with $\mathrm{OH}$, which mainly controls the conversion into sulphate aerosol (Weisenstein et al., 1997), an exponential decay rate of the number concentrations of $\mathrm{SO}_{2}$ can be derived (Seinfeld and Pandis, 2006);

$C_{\mathrm{SO}_{2}}^{n}(t)=C_{\mathrm{SO}_{2}}^{n}(0) \cdot \mathrm{e}^{-k t}$,

where $k$ is the loss rate constant. Since the depletion rate $C_{\mathrm{SO}_{2}}^{n}(t) / d t$ of $\mathrm{SO}_{2}$ molecules equals the production rate of $\mathrm{SO}_{4}$, the mass concentration ratio of $\mathrm{Fe}$ and $\mathrm{S}$ can be expressed as;

$\frac{C_{\mathrm{Fe}}^{n}}{C_{\mathrm{SO}_{4}}^{n}(t)} \propto \frac{C_{\mathrm{Fe}}^{m}}{C_{\mathrm{S}}^{m}(t)}=\frac{A}{1-e^{-k t}}$,

where $C^{n}$ and $C^{m}$ denotes number respective mass concentrations. The constant $A$ is the mass concentration ratio of $\mathrm{Fe}$ from ash and total $\mathrm{S}$ from $\mathrm{SO}_{2}$ that is eventually converted to sulphate. Since the composition of volcanic aerosol depends on the eruption characteristics (magma composition, explosivity, temperature, gas release etc., Mather et al., 2003) aerosol from different eruptive events cannot be expected to have similar Fe/S ratios. Still most samples collected following the Sarychev and Kasatochi eruptions show large similarities in their $\mathrm{Fe} / \mathrm{S}$ ratio with respect to age. Thus Eq. (2) was fitted to the $\mathrm{Fe} / \mathrm{S}$ ratio in Sarychev and Kasatochi 
samples, assuming similar emission ratio of $\mathrm{Fe} / \mathrm{S}$ in the eruptions. The logarithm of the $\mathrm{Fe} / \mathrm{S}$ ratios was used in the fitting to avoid over representing the large ratios appearing the first two weeks after the eruptions. Changed emissions during the eruptions as well as atmospheric conditions that affect mixing and transport also influence the composition of the aerosol. As stated earlier, the ash component was rather simple to recognize within two weeks after the eruption, and thereafter it was more influenced by other sources. Such influences could explain some of the deviations from the decreasing trend in Fig. 7. Also deviations from the average background concentrations used in the corrections have to be considered. Samples taken more than 100 days after the eruptions show large deviations from the general tendency, probably as the result of dilution of the volcanic cloud and mixing, and are excluded from the fit. One younger Sarychev sample shows large deviation compared to other samples collected at approximately the same time, and has therefore also been excluded.

Samples from the Eyjafjallajökull volcanic cloud was not included in this fit. As was seen in Fig. 5, the relative concentration of sulphate is low in samples from the Eyjafjallajökull eruption compared to the samples following Sarychev and Kasatochi, likely due to the large emissions of fine grained ash in the Eyjafjallajökull eruption (BGVN, 2010). In addition these samples were collected close to the eruption which implicates short time for conversion of $\mathrm{SO}_{2}$ into sulphate aerosol. However the residence time of $\mathrm{SO}_{2}$ in the troposphere where these samples were collected are considerably shorter than in the stratosphere, only hours to few days (McGonigle et al., 2004; Carn et al., 2011), leading to rapid conversion into sulphate aerosol. These samples should therefore not follow the same decay as those collected at higher altitudes. Also no background correction was made for the Eyjafjallajökull samples as mentioned earlier. An additional important aspect is initial processes in the volcanic cloud that lead to growth by aggregation and rapid sedimentation of fine ash particles (Rose et al., 2001). Such processes could be of importance during sampling in the Eyjafjallajökull volcanic clouds because they were only $1-2$ days old.

The residence time of $\mathrm{SO}_{2}(1 / \mathrm{k})$ in the tropopause region and LMS after the eruptions of Kasatochi and Sarychev was from the fitted curve estimated to be $45 \pm 22$ days (mean \pm standard error). The value of $A$, representing the ratio of total $\mathrm{Fe}$ and $\mathrm{S}$ was estimated to 0.0036 corresponding to a final ash $/ \mathrm{SO}_{4}$ mass ratio of approximately 0.016 for particles in the $0.08-2 \mu \mathrm{m}$ size range considered here.

\section{Discussion}

Previous estimates of residence time of $\mathrm{SO}_{2}$ for the volcanic cloud of Kasatochi span from 9 days (Krotkov et al., 2010), to 18 days (Karagulian et al., 2010) and up to 62 days (Jurkat et al., 2010). The residence time of $\mathrm{SO}_{2}$ following the Sarychev eruption has been estimated to 11 days (Haywood et al., 2010). Thus there is a large spread in estimated residence times. Estimations of the conversion rate of $\mathrm{SO}_{2}$ following the Pinatubo eruption are less dispersed; 35 days (Bluth and Doiron, 1992), 33 days (Read et al., 1993) and $25 \pm 5$ as well as $23 \pm 5$ days (Guo et al., 2004). Except in the work by Guo et al. (2004), uncertainty of the estimated residence time has not been given. Thus it is difficult to compare the validity of our estimate to others. While earlier estimates obtained for the Pinatubo eruption (satellite based) and by aircraft observations for Kasatochi (Jurkat et al., 2010) lie within our uncertainty limits, the results based on satellite observations of the Kasatochi and Sarychev volcanic clouds are considerably lower. The spread in estimated residence time, both between similar and dissimilar methods, underscore that it is valuable to perform calculations of $\mathrm{SO}_{2}$ residence time in different volcanic clouds and by different methods, and not only rely on the more consistent results from the Pinatubo eruption.

For the Kasatochi and Sarychev eruptions, it seems like the aircraft observations of volcanic clouds (Jurkat et al., 2010; this study) result in longer residence times than the satellite based measurements (see above). Haywood et al. (2010) argue that the detection limit of the IASI satellite measurements could lead to somewhat underestimated residence time (up to $50 \%$ ). Measurements following the Kasatochi eruption based on particle detection by OSIRIS on board the satellite Odin corresponded to a $\mathrm{SO}_{2}$ residence time of approximately 30 days (Bourassa et al., 2010). This points to that the difference between the Kasatochi measurements is connected to whether the measurements are based on detection of $\mathrm{SO}_{2}$ or particles rather than satellite or in situ. Heard et al. (2012) modelled $\mathrm{SO}_{2}$ and aerosol optical depth (AOD). Their results were compared with satellite observations from IASI and OSIRIS for the eruption of Sarychev. In their model $\mathrm{SO}_{2}$ remained longer and the particle concentration rose faster than in the observations. The detection limit of the satellite $\mathrm{SO}_{2}$ retrieval was suggested as a possible cause for the faster decrease of $\mathrm{SO}_{2}$ in observed data, while for the AOD the inadequately modelling of nucleation were proposed as the main reason for the earlier peak of the AOD in the model as particle reached the optically active accumulation mode to fast.

Aircraft measurements suffer from the difficulties to follow a volcanic cloud as it ages, and the sampling of volcanically influenced air at one position cannot be guaranteed to be representative for the whole volcanic cloud. The methodology used in this study demands that the ratio of ash and $\mathrm{SO}_{2}$ injected into the UT/LMS by the volcanoes were constant and that influence from coagulation has declined before the first measurement used in the estimate of the residence time. These assumptions are likely simplifications, where the former causes scatter in the data whereas coagulation would tend to cause a shorter estimate of residence time than the actual one. One important difference between 
the aircraft and satellite observations is that while the in-situ measurements are constrained to a well-defined altitude, the remote sensing $\mathrm{SO}_{2}$ instruments observes the whole atmospheric column. The altitude of the Kasatochi plume is estimated to $12.5 \pm 4 \mathrm{~km}$ by Karagulian et al. (2010) and 10$12 \mathrm{~km}$ by Krotkov et al. (2010). Mixing with tropospheric air, where residence times are shorter, cannot be excluded and would have affected the satellite based estimates. Krotkov et al. (2010) suggest the rather low altitude of the Kasatochi plume and the dynamic UT/LMS in the extra tropics as an explanation for why they derive a shorter $\mathrm{SO}_{2}$ residence time ( 9 days) compared to the one observed after the Pinatubo eruption, that injected material well into the stratosphere.

Finally differences in the actual residence times following the eruptions of Sarychev and Kasatochi compared to that following Pinatubo may well be caused by differences in the abundance of $\mathrm{OH}$. The latitudinal dependence could thereby be of significance as Pinatubo is located in the tropics $\left(15.13^{\circ} \mathrm{N}, 120.35^{\circ} \mathrm{E}\right)$ where $\mathrm{OH}$ concentrations are higher than at the mid-latitudes (Gross and Khalil, 2000), where the Kasatochi and Sarychev volcanoes are located, leading to longer residence times. Since the eruptions occurred in June (Pinatubo and Sarychev) and August (Kasatochi), there should be negligible differences in the $\mathrm{OH}$ concentration due to seasonal variation in the UV flux. An important factor is likely to be the altitude for which these estimates were made, since $\mathrm{OH}$ concentrations increase strongly above $\sim 20 \mathrm{~km}$ (Gross and Khalil, 2000). The results obtined in this study and by Jurkat et al. (2010) are based on aircraft measurements at altitudes of 7-12 km, which is just below the center of the volcanic cloud as observed by sattelites. The volcanic cloud that was observed by satellite following the Pinatubo eruption was injected well into the stratosphere to altitudes of $\sim 25 \mathrm{~km}$ (Guo et al., 2004). Thus the longer residence times meassured by aircraft might be typical for the altitude and latitude considered.

\section{Conclusions}

Volcanic aerosol have been collected in the tropopause region and lowermost stratosphere following major eruptions of the Kasatochi and Sarychev volcanoes, and in the troposphere in the volcanic cloud from the Eyjafjallajökull eruption in 2010. The main components of the volcanic aerosol were found to be sulphate, ash and carbonaceous material, where the source of the latter is proposed to be low-altitude tropospheric air that is entrained into the volcanic jet and plume. In samples collected in the volcanic cloud from Eyjafjallajökull ash and sulphate contributed approximately equal amounts to the total aerosol mass $(\sim 45 \%)$. In samples collected following Sarychev and Kasatochi ash was a minor part of the aerosol (1-7\%) while sulphate (50-77\%) and carbon (21$43 \%)$ were dominating. These fractions changed with the age of the aerosol. In this study we could follow the evolution of volcanic aerosol during more than twice the residence time of $\mathrm{SO}_{2}$ in a volcanic cloud. The first samples collected 1 and 1.5 weeks after the eruption of Kasatochi and Sarychev consisted of $14 \%$ and $5 \%$ ash relative to the mass of sulphate, respectively. After 10 and 11 weeks the ash component was still identifiable, but had decreased to about $2 \%$ relative to the sulphate mass for both eruptions. The ash/sulphate ratio of aerosol collected following the Kasatochi and Sarychev eruptions showed a decreasing trend. From this decay the residence time of $\mathrm{SO}_{2}$ in the tropopause region and lowermost stratosphere was estimated to be $45 \pm 22$ days. Previous estimates of $\mathrm{SO}_{2}$ residence time following the Kasatochi and Sarychev eruptions by different methods based on $\mathrm{SO}_{2}$ or sulphate detection as well as in situ or remote sensing from satellites, are of the same magnitude although distributed over a rather wide range from 9 to 62 days. In contrast more consistent residence times was observed from satellite measurements following the large eruption of Pinatubo in 1991. This emphasizes that it is more difficult to measure the conversion rates of $\mathrm{SO}_{2}$ after intermediate eruptions. The difficulties could be connected with variability in composition, detection problem and/or the altitude distribution of $\mathrm{SO}_{2}$ after the eruptions.

Acknowledgements. We thank all members of the CARIBIC team, especially C. Koeppel, D. S. Scharffe and S. Weber. The collaboration with Lufthansa and Lufthansa Technik is gratefully acknowledged. Aerosol measurements from CALIPSO were produced by NASA Langley Research Center. Financial support from the Swedish Research Council and the Swedish Research Council for Environments, Agricultural Sciences and Spatial Planning under grants 621-2007-4639 and 214-2009-613 is gratefully acknowledged.

Edited by: W. Birmili

\section{References}

Ammann, C. M., Meehl, G. A., Washington, W. M., and Zender, C. S.: A monthly and latitudinally varying volcanic forcing dataset in simulations of 20th century climate, Geophys. Res. Lett., 30, 1657-1661, doi:10.1029/2003GL016875, 2003.

Andreae, M. O., Wienhold, F. G., Zenker, T., Andreae, T. W., Annegarn, H., Beer, J., Cachier, H., le Canut, P., Elbert, W., Maenhaut, W., and Salma, I.: Airborne studies of aerosol emissions from savanna fires in southern Africa: 2. Aerosol chemical composition, J. Geophys Res., 103, 32119-32128, doi:10.1029/98JD02280, 1998.

Baker, A. K., Rauthe-Schöch, A., Schuck, T. J., Brenninkmeijer, C. A. M., van Velthoven, P. F. J., Wisher, A., and Oram, D. E.: Investigation of chlorine radical chemistry in the Eyjafjallajökull volcanic plume using observed depletions in non-methane hydrocarbons, Geophys. Res. Lett., 38, L13801, doi:10.1029/2011GL047571, 2011. 
Bauman, J. J., Russell, P. B., Geller, M. A., and Patrick, H.: A stratospheric aerosol climatology from SAGE II and CLAES measurements: 2. Results and comparisons, 1984-1999, J. Geophys. Res., 108, 4383, doi:10.1029/2002jd002993, 2003.

BGVN, B. o. t. G. V. N.: Widespread plumes from large 11-16 June 2009 eruption34:06, 2009.

BGVN, B. o. t. G. V. N.: Large explosions from the summit crater; ash plumes close airspace in Europe, 35:04, 2010.

Bluth, G. J. S. and Doiron, S. D.: Global tracking of the SO2 clouds from the june, 1991 mount pinatubo eruptions, Geophys. Res. Lett., 19, 51-154, 1992.

Bourassa, A. E., Degenstein, D. A., Elash, B. J., and Llewellyn, E. J.: Evolution of the stratospheric aerosol enhancement following the eruptions of Okmok and Kasatochi: OdinOSIRIS measurements, J. Geophys. Res., 115, D00L03, doi:10.1029/2009jd013274, 2010.

Brenninkmeijer, C. A. M., Crutzen, P., Boumard, F., Dauer, T., Dix, B., Ebinghaus, R., Filippi, D., Fischer, H., Franke, H., Friess, U., Heintzenberg, J., Helleis, F., Hermann, M., Kock, H. H., Koeppel, C., Lelieveld, J., Leuenberger, M., Martinsson, B. G., Miemczyk, S., Moret, H. P., Nguyen, H. N., Nyfeler, P., Oram, D., O’Sullivan, D., Penkett, S., Platt, U., Pupek, M., Ramonet, M., Randa, B., Reichelt, M., Rhee, T. S., Rohwer, J., Rosenfeld, K., Scharffe, D., Schlager, H., Schumann, U., Slemr, F., Sprung, D., Stock, P., Thaler, R., Valentino, F., van Velthoven, P., Waibel, A., Wandel, A., Waschitschek, K., Wiedensohler, A., Xueref-Remy, I., Zahn, A., Zech, U., and Ziereis, H.: Civil Aircraft for the regular investigation of the atmosphere based on an instrumented container: The new CARIBIC system, Atmos. Chem. Phys, 7, 4953-4976, doi:10.5194/acp-7-4953-2007, 2007.

Carey, S. N. and Sigurdsson, H.: Influence of particle aggregation on deposition of distal tephra from the may 18, 1980, eruption of Mount St. Helens volcano, J. Geophys. Res., 87, 7061-7072, 1982.

Carn, S. A., Krueger, A. J., Krotkov, N. A., Yang, K., and Evans, K.: Tracking volcanic sulfur dioxide clouds for aviation hazard mitigation, Nat. Hazards, 51, 325-343, doi:10.1007/s11069-0089228-4, 2009.

Carn, S. A., Froyd, K. D., Anderson, B. E., Wennberg, P., Crounse, J., Spencer, K., Dibb, J. E., Krotkov, N. A., Browell, E. V., Hair, J. W., Diskin, G., Sachse, G., and Vay, S. A.: In situ measurements of tropospheric volcanic plumes in Ecuador and Colombia during TC4, J. Geophys. Res., 116, D00J24, doi:10.1029/2010jd014718, 2011.

Casadevall, T. J.: The 1989-1990 eruption of Redoubt Volcano, Alaska: impacts on aircraft operations, J. Volcanol. Geoth. Res., 62, 301-316, doi:10.1016/0377-0273(94)90038-8, 1994.

Chin, M. and Davis, D. D.: A reanalysis of carbonyl sulfide as a source of stratospheric background sulfur aerosol, J Geophys. Res., 100, 8993-9005, 1995.

Crutzen, P. J.: The possible importance of CSO for the sulfate layer of the stratosphere, Geophys. Res. Lett., 3, 73-76, doi:10.1029/GL003i002p00073, 1976.

Cziczo, D. J., Thomson, D. S., and Murphy, D. M.: Ablation, Flux, and Atmospheric Implications of Meteors Inferred from Stratospheric Aerosol, Science, 291, 1772-1775, 2001.

Deshler, T.: A review of global stratospheric aerosol: Measurements, importance, life cycle, and local stratospheric aerosol, Atmos. Res., 90, 223-232, doi:10.1016/j.atmosres.2008.03.016,
2008.

Deshler, T., Hervig, M., Hofmann, D., Rosen, J., and Liley, J.: Thirty years of in situ stratospheric aerosol size distribution measurements from Laramie, Wyoming $\left(41^{\circ} \mathrm{N}\right)$, using balloon-borne instruments, J. Geophys. Res., 108, 4167, doi:10.1029/2002JD002514, 2003.

Dix, B., Brenninkmeijer, C. A. M., Frieß, U., Wagner, T., and Platt, U.: Airborne multi-axis DOAS measurements of atmospheric trace gases on CARIBIC long-distance flights, Atmos. Meas. Tech., 2, 639-652, doi:10.5194/amt-2-639-2009, 2009.

Ferry, G. V., Pueschel, R. F., Strawa, A. W., Kondo, Y., Howard, S. D., Verma, S., Mahoney, M. J., Bui, T. P., Hannan, J. R., and Fuelberg, H. E.: Effects of aircraft on aerosol abundance in the upper troposphere, Geophys. Res. Lett., 26, 2399-2402, doi:10.1029/1999GL900445, 1999.

Fromm, M., Bevilacqua, R., Stocks, B., and Servranckx, R.: New Directions: Eruptive Transport to the Stratosphere: Add Fire-Convection to Volcanoes, Atmos. Environ., 38, 163-165, doi:10.1016/j.atmosenv.2003.10.001, 2004.

Fromm, M., Shettle, E. P., Fricke, K. H., Ritter, C., Trickl, T., Giehl, H., Gerding, M., Barnes, J. E., Neill, M. O., Massie, S. T., Blum, U., McDermid, I. S., Leblanc, T., and Deshler, T.: Stratospheric impact of the Chisholm pyrocumulonimbus eruption: 2. Vertical profile perspective, J. Geophys. Res., 113, D08203, doi:10.1029/2007jd009147, 2008.

Gross, G. W. and Khalil, M. A. K.: OH concentrations from a general circulation model coupled with a tropospheric chemistry model, Chemosphere - Global Change Science, 2, 191-206, doi:10.1016/s1465-9972(99)00054-9, 2000.

Guan, H., Esswein, R., Lopez, J., Bergstrom, R., Warnock, A., Follette-Cook, M., Fromm, M., and Iraci, L. T.: A multidecadal history of biomass burning plume heights identified using aerosol index measurements, Atm. Chem. Phys., 10, 64616469, doi:10.5194/acp-10-6461-2010, 2010.

Guo, S., Bluth, G., J. S., Rose, W. I., Watson, I. M., and Prata, A. J.: Re-evaluation of SO2 release of the 15 June 1991 Pinatubo eruption using ultraviolet and infrared satellite sensors, Geochem. Geophy. Geosy., 5, Q04001, doi:10.1029/2003GC000654, 2004.

Hand, J. L., Schichtel, B. A., Pitchford, M., Malm, W. C., and Frank, N. H.: Seasonal composition of remote and urban fine particulate matter in the United States, J. Geophys. Res., 117, D05209, doi:10.1029/2011JD017122, 2012.

Haywood, J. M., Clerbaux, C., Coheur, P., Degenstein, D., Braesicke, P., Jones, A., Clarisse, L., Bourassa, A., Barnes, J., Telford, P., Bellouin, N., Boucher, O., and Agnew, P.: Observations of the eruption of the Sarychev volcano and simulations using the HadGEM2 climate model, J. Geophys. Res., 115, D21212, doi:10.1029/2010JD014447, 2010.

Heard, I. P. C., Manning, A. J., Haywood, J. M., Witham, C., Redington, A., Jones, A., Clarisse, L., and Bourassa, A.: A comparison of atmospheric dispersion model predictions with observations of $\mathrm{SO}_{2}$ and sulphate aerosol from volcanic eruptions, J. Geophys. Res., 117, D00U22, doi:10.1029/2011JD016791, 2012.

Heiken, G. and Wohletz, K.: Volcanic ash, University of California Press, Berkeley, 1985.

Heue, K. P., Brenninkmeijer, C. A. M., Baker, A. K., RautheSchoch, A., Walter, D., Wagner, T., Hormann, C., Sihler, H., Dix, B., Friess, U., Platt, U., Martinsson, B. G., van Velthoven, P. 
F. J., Zahn, A., and Ebinghaus, R.: SO2 and BrO observation in the plume of the Eyjafjallajokull volcano 2010: CARIBIC and GOME-2 retrievals, Atmos. Chem. Phys, 11, 2973-2989, doi:10.5194/acp-11-2973-2011, 2011.

Hinds, W. C.: Aerosol technology: properties, behavior, and measurement of airborne particles, Book, John Wiley \& Sons, New York, USA, 1999.

Hinkley, T. K., Le Cloarec, M. F., and Lambert, G.: Fractionation of families of major, minor, and trace metals across the melt-vapor interface in volcanic exhalations, Geochim. Cosmochim. Ac., 58, 3255-3263, doi:10.1016/0016-7037(94)90053-1, 1994.

Hofmann, D., Barnes, J., O’Neill, M., Trudeau, M., and Neely, R.: Increase in background stratospheric aerosol observed with lidar at Mauna Loa Observatory and Boulder, Colorado, Geophys. Res. Lett., 36, L15808, doi:10.1029/2009GL039008, 2009.

IPCC: Climate Change 2007: The Physical Science Basis. Contribution of Working Group I to the Fourth Assessment Report of the Intergovernmental Panel on Climate Change, edited by: Solomon, S., Qin, D., Manning, M., Chen, Z., Marquis, M., Averyt, K. B., Tignor, M., and Miller, H. L., Cambridge University Press, Cambridge, United Kingdom and New York, NY, USA, 2007.

Jimenez, J. L., Canagaratna, M. R., Donahue, N. M., Prevot, A. S., Zhang, Q., Kroll, J. H., DeCarlo, P. F., Allan, J. D., Coe, H., Ng, N. L., Aiken, A. C., Docherty, K. S., Ulbrich, I. M., Grieshop, A. P., Robinson, A. L., Duplissy, J., Smith, J. D., Wilson, K. R., Lanz, V. A., Hueglin, C., Sun, Y. L., Tian, J., Laaksonen, A., Raatikainen, T., Rautiainen, J., Vaattovaara, P., Ehn, M., Kulmala, M., Tomlinson, J. M., Collins, D. R., Cubison, M. J., Dunlea, E. J., Huffman, J. A., Onasch, T. B., Alfarra, M. R., Williams, P. I., Bower, K., Kondo, Y., Schneider, J., Drewnick, F., Borrmann, S., Weimer, S., Demerjian, K., Salcedo, D., Cottrell, L., Griffin, R., Takami, A., Miyoshi, T., Hatakeyama, S., Shimono, A., Sun, J. Y., Zhang, Y. M., Dzepina, K., Kimmel, J. R., Sueper, D., Jayne, J. T., Herndon, S. C., Trimborn, A. M., Williams, L. R., Wood, E. C., Middlebrook, A. M., Kolb, C. E., Baltensperger, U., and Worsnop, D. R.: Evolution of organic aerosols in the atmosphere, Science, 326, 1525-1529, doi:10.1126/science.1180353, 2009.

Johansson, S. A. E. and Campbell, J. L.: PIXE: A novel technique for elemental analysis, John Wiley \& Sons, New York, 1988.

Junge, C. E., Chagnon, C. W., and Manson, J. E.: A Worldwide Stratospheric Aerosol Layer, Science, 133, 1478-1479, doi:10.1126/science.133.3463.1478-a, 1961.

Jurkat, T., Voigt, C., Arnold, F., Schlager, H., Aufmhoff, H., Schmale, J., Schneider, J., Lichtenstern, M., and Dornbrack, A.: Airborne stratospheric ITCIMS measurements of $\mathrm{SO}_{2}, \mathrm{HCl}$, and $\mathrm{HNO}_{3}$ in the aged plume of volcano Kasatochi, J. Geophys. Res., 115, D00L17, doi:10.1029/2010JD013890, 2010.

Jäger, H.: Long-term record of lidar observations of the stratospheric aerosol layer at Garmisch-Partenkirchen, J. Geophys. Res., 110, D08106, doi:10.1029/2004jd005506, 2005.

Karagulian, F., Clarisse, L., Clerbaux, C., Prata, A. J., Hurtmans, D., and Coheur, P. F.: Detection of volcanic SO2, ash, and H2SO4 using the Infrared Atmospheric Sounding Interferometer (IASI), J. Geophys. Res., 115, D00L02, doi:10.1029/2009JD012786, 2010.

Kjellström, E., Feichter, J., Sausenc, R., and Hein, R.: The contribution of aircraft emissions to the atmospheric sulfur budget,
Atmos. Environ., 33, 3455-3465, 1999.

Kopp, E.: On the abundance of metal ions in the lower ionosphere, J. Geophys. Res., 102, 9667-9674, doi:10.1029/97ja00384, 1997.

Krotkov, N. A., Schoeberl, M. R., Morris, G. A., Carn, S., and Yang, K.: Dispersion and lifetime of the $\mathrm{SO}_{2}$ cloud from the August 2008 Kasatochi eruption, J. Geophys. Res., 115, D00L20, doi:10.1029/2010JD013984, 2010.

Köppe, M., Hermann, M., Brenninkmeijer, C. A. M., Heintzenberg, J., Schlager, H., Schuck, T., Slemr, F., Sprung, D., Velthoven, P. F. J. v., Wiedensohler, A., Zahn, A., and Ziereis, H.: Origin of aerosol particles in the mid-latitude and subtropical upper troposphere and lowermost stratosphere from cluster analysis of CARIBIC data, Atmos. Chem. Phys., 9, 8413-8430, doi:10.5194/acp-9-8413-2009, 2009.

Lopez, T. M., Carn, S. A., Webley, P., and Pfeffer, M. A.: Evaluation of satellite derived sulfur dioxide measurements for volcano monitoring during the 2009 Redoubt eruption American Geophysical Union, Fall Meeting 2009, abstract \#V51F-03, 2009.

Martinsson, B. G., Nguyen, H. N., Brenninkmeijer, C. A. M., Zahn, A., Heintzenberg, J., Hermann, M., and Velthoven, P. F. J. v.: Characteristics and origin of lowermost stratospheric aerosol at northern midlatitudes under volcanically quiescent conditions based on CARIBIC observations, J. Geophys. Res., 110, D12201, doi:10.1029/2004JD005644, 2005.

Martinsson, B. G., Brenninkmeijer, C. A. M., Carn, S. A., Hermann, M., Heue, K. P., Velthoven, P. F. J. v., and Zahn, A.: Influence of the 2008 Kasatochi volcanic eruption on sulfurous and carbonaceous aerosol constituents in the lower stratosphere, Geophys. Res. Lett., 36, L12813, doi:10.1029/2009g1038735, 2009.

Mather, T. A., Pyle, D. M., and Oppenheimer, C.: Tropospheric Volcanic Aerosol, Geophys. Monogr., 139, 189-212, doi:10.1029/139GM12, 2003.

McCormick, M. P., Thomason, L. W., and Trepte, C. R.: Atmospheric effects of the Mt Pinatubo eruption, Nature, 373, 399404, doi:10.1038/373399a0, 1995.

McGonigle, A. J. S., Delmelle, P., Oppenheimer, C., Tsanev, V. I., Delfosse, T., Williams-Jones, G., Horton, K., and Mather, T. A.: $\mathrm{SO}_{2}$ depletion in tropospheric volcanic plumes, Geophys. Res. Lett., 31, L13201, doi:10.1029/2004g1019990, 2004.

Moune, S., Gauthier, P.-J., Gislason, S. R., and Sigmarsson, O.: Trace element degassing and enrichment in the eruptive plume of the 2000 eruption of Hekla volcano, Iceland, Geochim. Cosmochim. Ac., 70, 461-479, doi:10.1016/j.gca.2005.09.011, 2005.

Murphy, D. M., Thomson, D. S., and Mahoney, M. J.: In situ measurements of organics, meteoritic matierial, mercury, and other elements in aerosols at 5 to 19 kilometers, Science, 282, 16641669, 1998.

Murphy, D. M., Cziczo, D. J., Hudson, P. K., and Thomson, D. S.: Carbonaceous material in aerosol particles in the lower stratosphere and tropopause region, J. Geophys. Res., 112, D04203, doi:10.1029/2006JD007297, 2007.

Myhre, G., Berglen, T. F., Myhre, C. E. L., and Isaksen, I. S. A.: The radiative effect of the anthropogenic influence on the stratospheric sulfate aerosol layer, Tellus B, 56, 294-299, doi:10.1111/j.1600-0889.2004.00106.x, 2004.

Newhall, C. G. and Self, S.: The Volcanic Explosivity Index (VEI): An Estimate of Explosive Magnitude for Historical Volcanism, J. Geophys. Res., 87, 1231-1238, doi:10.1029/JC087iC02p01231, 
1982.

Nguyen, H. N. and Martinsson, B. G.: Analysis of C, N and O in aerosol collected on an organic backing using internal blank measurements and variable beam size, Nucl. Instrum. Methods, 264, 96-102, 10.1016/j.nimb.2007.08.001, 2007.

Nguyen, N. H., Gudmundsson, A., and Martinsson, B.: Design and calibration of a multi-channel aerosol sampler for tropopause region studies from the CARIBIC platform, Aerosol Sci. Tech., 40, 649-655, doi:10.1080/02786820600767807, 2006.

Nguyen, H. N., Martinsson, B. G., Wagner, J. B., Carlemalm, E., Ebert, M., Weinbruch, S., Brenninkmeijer, C. A. M., Heintzenberg, J., Hermann, M., Schuck, T., Velthoven, P. F. J. v., and Zahn, A.: Chemical composition and morphology of individual aerosol particles from a CARIBIC flight at $10 \mathrm{~km}$ altitude between $50^{\circ} \mathrm{N}$ and $30^{\circ} \mathrm{S}$, J. Geophys. Res., 113, D23209, doi:10.1029/2008JD009956, 2008.

Niemeier, U., Timmreck, C., Graf, H.-F., Kinne, S., Rast, S., and Self, S.: Initial fate of fine ash and sulfur from large volcanic eruptions, Atmos. Chem. Phys., 9, 9043-9057, doi:10.5194/acp9-9043-2009, 2009.

O’Dowd, C. D., Facchini, M. C., Cavalli, F., Ceburnis, D., Mircea, M., Decesari, S., Fuzzi, S., Yoon, Y. J., and Putaud, J.-P.: Biogenically driven organic contribution to marine aerosol, Nature, 431, 676-680, doi:10.1038/nature02959, 2004.

Papaspiropoulos, G., Martinsson, B. G., Zahn, A., Brenninkmeijer, C. A. M., Hermann, M., Heintzenberg, J., Fischer, H., and Velthoven, P. F. J. v.: Aerosol elemental concentrations in the tropopause region from intercontinental flights with the Civil Aircraft for Regular Investigation of the Atmosphere Based on an Instrument Container (CARIBIC) platform, J. Geophys. Res., 107, 4671, doi:10.1029/2002jd002344, 2002.

Pitari, G., Mancini, E., Rizi, V., and Shindell, D. T.: Impact of Future Climate and Emission Changes on Stratospheric Aerosols and Ozone, J. Atmos. Sci., 59, 414-440, doi:10.1175/15200469(2002)059<0414:iofcae>2.0.co; 2, 2002.

Rauthe-Schöch, A., Weigelt, A., Hermann, M., Martinsson, B. G., Baker, A. K., Heue, K.-P., Brenninkmeijer, C. A. M., Zahn, A., Scharffe, D., Eckhardt, S., Stohl, A., and Velthoven, P. F. J. v.: CARIBIC aircraft measurements of Eyjafjallajökull volcanic plumes in April/May 2010, Atmos. Chem. Phys., 12, 879-902, doi:10.5194/acp-12-879-2012, 2012.

Read, W. G., Froidevaux, L., and Waters, J. W.: Microwave Limb Sounder measurement of stratospheric SO2 from the Mt. Pinatubo volcano, Geophys. Res. Lett., 20, 1299-1302, 1993.

Rose, W. I. and Durant, A. J.: Fine ash content of explosive eruptions, J. Volcanol. Geoth. Res., 186, 32-39, doi:10.1016/j.jvolgeores.2009.01.010, 2009.

Rose, W. I., Bluth, G. J. S., Schneider, D. J., Ernst, G. G. J., Riley, C. M., Henderson, L. J., and McGimsey, R. G.: Observations of Volcanic Clouds in Their First Few Days of Atmospheric Residence: The 1992 Eruptions of Crater Peak, Mount Spurr Volcano, Alaska, J. Geol., 109, 677-694, 10.1086/323189, 2001.

Rubin, K.: Degassing of metals and metalloids from erupting seamount and mid-ocean ridge volcanoes: Observations and predictions, Geochim. Cosmochim. Ac., 61, 3525-3542, doi:10.1016/s0016-7037(97)00179-8, 1997.

Rudnic, L. R. and Fountain, M. D.: Nature and composition of the continental crust: a lower crustal perspective, Rev. Geophys., 33, 267-309, doi:10.1029/95RG01302, 1995.
Scheele, M. P., Siegmund, P. C., and Velthoven, P. F. J. V.: Sensitivity of trajectories to data resolution and its dependence on the starting point: In or outside a tropopause fold, Meteorol. Appl., 3, 267-273, doi:10.1002/met.5060030308, 1996.

Schmale, J., Schneider, J., Voigt, T. J., Kalesse, H., Rautenhaus, M., Lichtenstern, M., Schlager, H., Ancellet, G., Arnold, F., Gerding, M., Mattis, I., Wendisch, M., and Borrmann, S.: Aerosol layers from the 2008 eruptions of Mount Okmok and Mount Kasatochi: In situ upper troposphere and lower stratosphere measurements of sulfate and organics over Europe, J. Geophys. Res., 115, D00L07, doi:10.1029/2009JD013628, 2010.

Schumann, U., Weinzierl, B., Reitebuch, O., Schlager, H., Minikin, A., Forster, C., Baumann, R., Sailer, T., Graf, K., Mannstein, H., Voigt, C., Rahm, S., Simmet, R., Scheibe, M., Lichtenstern, M., Stock, P., Ruba, H., Schauble, D., Tafferner, A., Rautenhaus, M., Gerz, T., Ziereis, H., Krautstrunk, M., Mallaun, C., Gayet, J. F., Lieke, K., Kandler, K., Ebert, M., Weinbruch, S., Stohl, A., Gasteiger, J., Gross, S., Freudenthaler, V., Wiegner, M., Ansmann, A., Tesche, M., Olafsson, H., and Sturm, K.: Airborne observations of the Eyjafjalla volcano ash cloud over Europe during air space closure in April and May 2010, Atmos. Chem. Phys, 11, 2245-2279, doi:10.5194/acp-11-2245-2011, 2011.

Seinfeld, J. H. and Pandis, S. N.: Atmospheric chemistry and physics: from air pollution to climate change, 2nd edn., Book, John Wiley\&Sons, Inc., Hoboken, N.J, 2006.

Sigmundsson, F., Hreinsdóttir, S., Hooper, A., Árnadóttir, T., Pedersen, R., Roberts, M. J., Óskarsson, N., Auriac, A., and Decriem, J.: Intrusion triggering of the 2010 Eyjafjallajökull explosive eruption, Nature 468, 426-430, doi:10.1038/nature09558, 2010.

Solomon, S., Daniel, J. S., Neely III, R. R., Vernier, J. P., Dutton, E. G., and Thomason, L. W.: The persistently variable "background" stratospheric aerosol layer and global climate change, Science, 333, 866-870, doi:10.1126/science.1206027, 2011.

Spracklen, D. V., Arnold, S. R., Sciare, J., Carslaw, K. S., and Pio, C.: Globally significant oceanic source of organic carbon aerosol, Geophys. Res.Lett., 35, L12811, doi:10.1029/2008GL033359, 2008.

Stramska, M.: Particulate organic carbon in the global ocean derived from SeaWiFS ocean color, Deep-Sea Research Part I, 56, 14591470, doi:10.1016/j.dsr.2009.04.009, 2009.

Suzuki, Y. J. and Koyaguchi, T.: Numerical determination of the efficiency of entrainment in volcanic eruption columns, Geophys. Res. Lett., 37, L05302, doi:10.1029/2009GL042159, 2010.

Thomas, H. E. and Prata, A. J.: Sulphur dioxide as a volcanic ash proxy during the April-May 2010 eruption of Eyjafjallajökull Volcano, Iceland, Atmos. Chem. Phys, 11, 6871-6880, doi:10.5194/acp-11-6871-2011, 2011.

Vernier, J.-P., Thomason, L. W., Pommereau, J.-P., Bourassa, A., Pelon, J., Garnier, A., Hauchecorne, A., Blanot, L., Trepte, C., Degenstein, D., and Vargas, F.: Major influence of tropical volcanic eruptions on the stratospheric aerosol layer during the last decade, Geophys. Res. Lett., 38, L12807, doi:10.1029/2011GL047563, 2011.

von Glasow, R., Bobrowski, N., and Kern, C.: The effects of volcanic eruptions on atmospheric chemistry, Chem. Geol., 263, 131-142, doi:10.1016/j.chemgeo.2008.08.020, 2009.

Waythomas, C. F., Scott, W. E., Prejean, S. G., Schneider, D. J., Izbekov, P., and Nye, C. J.: The 7-8 August 2008 eruption of 
Kasatochi Volcano, central Aleutian Islands, Alaska, J. Geophys. Res., 115, B00B06, doi:10.1029/2010jb007437, 2010.

Weisenstein, D. K., Yue, G. K., Ko, M. K. W., Sze, N.-D., Rodriguez, J. M., and Scott, C. J.: A two-dimensional model of sulfur species and aerosols, J. Geophys. Res., 102, 13019-13035, doi:10.1029/97JD00901 1997.

Winker, D. M., Vaughan, M. A., Omar, A., Hu, Y. X., Powell, K. A., Liu, Z. Y., Hunt, W. H., and Young, S. A.: Overview of the CALIPSO Mission and CALIOP Data Processing Algorithms, J. Atmos. Ocean. Tech., 26, 2310-2323, doi:10.1175/2009jtecha1281.1, 2009.

Witham, C. S., Oppenheimer, C., and Horwell, C. J.: Volcanic ash-leachates: a review and recommendations for sampling methods, J. Volcanol. Geoth. Res., 141, 299-326, doi:10.1016/j.jvolgeores.2004.11.010, 2005.

Yang, K., Liu, X. O., Bhartia, P. K., Krotkov, N. A., Carn, S. A., Hughes, E. J., Krueger, A. J., Spurr, R. J. D., and Trahan, S. G.: Direct retrieval of sulfur dioxide amount and altitude from spaceborne hyperspectral UV measurements: Theory and application, J. Geophys. Res., 115, D00L09, doi:10.1029/2010jd013982, 2010.
Yoon, Y. J., Jennings, S. G., Dowd, C. D. O., Ceburnis, D., Cavalli, F., Jourdan, O., Putaud, J. P., Facchini, M. C., Decesari, S., Fuzzi, S., and Sellegri, K.: Seasonal characteristics of the physicochemical properties of North Atlantic marine atmospheric aerosols, J. Geophys. Res., 112, D04206, doi:10.1029/2005JD007044, 2007.

Yue, G. K., Poole, L. R., Wang, P. H., and Chiou, E. W.: Stratospheric aerosol acidity, density, and refractive index deduced from SAGE II and NMC temperature data J. Geophys. Res., 99, 3727-3738, doi:10.1029/93jd02989, 1994.

Zahn, A., Weppner, J., Widmann, H., Schlote-Holubek, K., Burger, B., Kuhner, T., and Franke, H.: A fast and precise chemiluminescence ozone detector for eddy flux and airborne application, Atmos. Meas. Tech., 5, 363-375, doi:10.5194/amt-5-363-2012, 2012. 